SALVATORE VITALE ${ }^{\mathrm{a}}$ - LAURA LUONGO - GIAN PAOLO BARZANTI ${ }^{\mathrm{b}}$ - FRANCESCO BINAZZI ${ }^{\mathrm{b}}$ MARIANGELA PETRUCCI ${ }^{\mathrm{a}}$ - MASSIMO GALLI ${ }^{\mathrm{a}}$ - FABRIZIO PENNACCHIO ${ }^{\mathrm{b}}$ - VALERIA FRANCARDI ${ }^{\mathrm{b}}$

\title{
FIRST REPORT OF GEOSMITHIA PALLIDA AND G. LANGDONII ASSOCIATED WITH LIPARTHRUM COLCHICUM IN CENTRAL ITALY
}

\author{
${ }^{a}$ CREA Research Centre for Plant Protection and Certification, Via C.G. Bertero, 22, 00156, Roma (Italy). \\ ${ }^{b}$ CREA Research Centre for Plant Protection and Certification, Via Lanciola 12A - 50125 Cascine del Riccio, \\ Impruneta, Florence (Italy).
}

Corresponding Author: salvatore.vitale@crea.gov.it.

Vitale S., Luongo L., Barzanti G.P., Binazzi F., Petrucci M., Galli M., Pennacchio F., Francardi V. - First report of Geosmithia pallida and G. langdonii associated with Lipartrhrum colchicum in central Italy.

Bark and wood-boring beetles feeding on coniferous and deciduous trees in different forest ecosystems are often associated with various species of fungi. In 2019, widespread attacks of Liparthrum colchicum Semenov (Coleoptera Curculionidae Scolytinae) were observed on Laurus nobilis L. in Tuscany (Italy). Samples of colonized terminal twigs were collected to investigate the presence of phytopathogenic fungi associated with the scolytid. Two different colonies of the Geosmithia genus were identified as Geosmithia pallida and Geosmithia langdonii. To our knowledge this is the first report of G.pallida and G. langdonii associated with L. colchicum on Bay tree, in Italy.

KEY WORDS: Liparthrum colchicum, Laurus nobilis, Geosmithia spp., Italy

\section{INTRODUCTION}

Bark and ambrosia beetles (Curculionidae: Scolytinae and Platypodinae) are pests threatening woody plants (e.g. timber plantations) all over the world. They are often associated with different communities of fungi including symbiont and phytopathogenic species. In the last two years (2019 - 2020), during extensive field surveys in different locations of Tuscany and Latium aimed at investigating the presence of a recently introduced scolytid, the black twig borer Xylosandrus compactus (Einchoff) on Laurus nobilis L., a second species, Liparthrum colchicum Semenov (Coleoptera Curculionidae Scolytinae), was identified in separate galleries on the same colonized twigs.

Liparthrum colchicum is a relatively unknown monophagous insect species primarily associated with thin dried twigs of about $0.5-1 \mathrm{~cm}$ in diameter of $L$. nobilis. (JORDAL et al., 2004) (Fig. I). This scolytid, which is currently considered a Mediterranean species, was reported for the first time in Italy as an intercepted organism alien to the country (RASSATI et al., 2015). However, because of the frequency of records along the Tyrrhenian coasts and the surrounding areas, it might be considered as an established species or even as an insect native to Italy (FRANCARDI et al., 2021). L. colchicum is normally attracted to moderate or even extremely dehydrated plant material and its populations have been overlooked so far due to their sporadic presence on the host plant. Nonetheless, L. colchicum infestations have recently increased becoming more evident due to the invasive presence on laurel trees of $X$. compactus, a much more harmful scolytid species that primarily attacks terminal twigs causing their progressive withering and thus increasing potential L. colchicum colonization. This species, which overwinters at larval or adult stages, is monogynous with two generations per year. Females enter dried twigs through an entrance hole below $1 \mathrm{~mm}$ $(0.6-0.7 \mathrm{~mm})$ in diameter. In Tuscany the reproductive activity of $L$. colchicum wintering adults was observed between May and June (FRANCARDI et al., 2021). L. colchicum attacks on twigs appear as typical lighter yellowish areas indicating the presence of maternal gallery under the epidermis where females have laid single eggs in niches. Larvae dig longitudinal feeding galleries that deeply excavate the surface of the sapwood. The possible role of $L$. colchicum as a vector of phytopathogenic fungi of the genus Geosmithia (Ascomycota, Hypocreales), in particular Geosmithia putterillii Thom. Pitt (Ascomycota, Hypocreales), has been reported by KolAŘ́K et al. $(2004,2007)$ in France. More recently, fungi belonging to the genus Geosmithia associated with $L$. colchicum have been also recorded in Italy (BENVENUTI et al., 2021).

This study aims to investigate in more detail the presence of phytopathogenic fungi associated with this scolytid.

\section{MATERIALS AND METHODS}

In Autumn 2019, terminal twigs of Bay trees with evident symptoms of $L$. colchicum attacks and fungal infections were collected in the park of Villa Salviati (Pisa), Tuscany. Adults of L. colchicum Semenov obtained from the wood galleries were kept in Petri dishes for about 1-3 h on Potato Dextrose Agar (PDA) medium; dishes were then incubated for 7 days at $24^{\circ} \mathrm{C}$. After this period, fungal colonies cream to tan colored, and tan to yellow-tan on the reverse side of the plate were observed on half-strength PDA. Purified cultures were grouped according to culture morphology using a micro- 


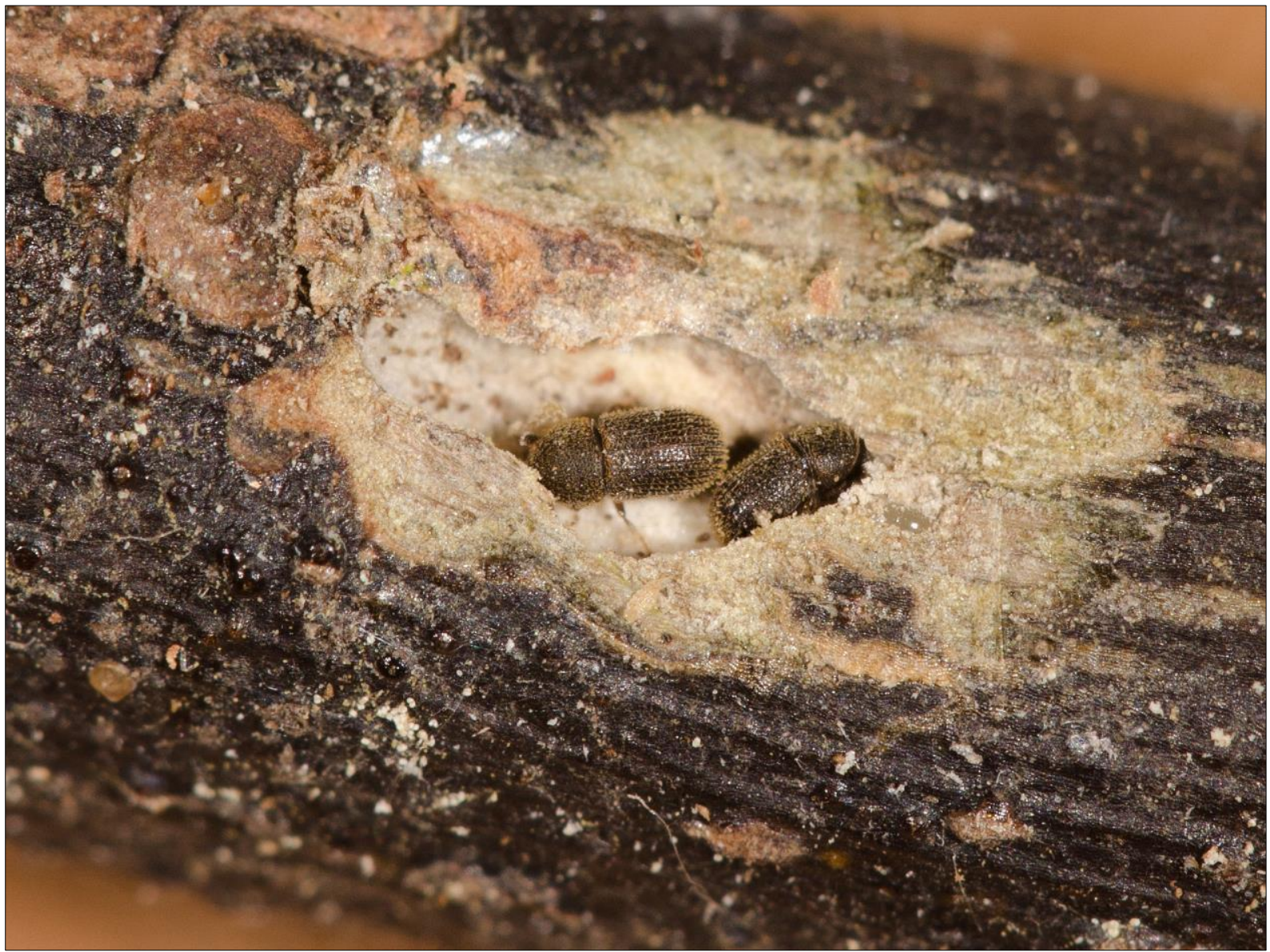

Fig. I - Liparthrum colchicum: adults within a typical maternal gallery

scope Zeiss Axio Imager A1 equipped with a Zeiss Axiocam 506 colour digital camera.

The DNA of two monosporic isolates (CREADC-F2469, CREADC-F2470) was extracted for molecular identification, following the protocol of the Wizard genomic DNA purification kit (Promega, Madison, WI, USA). The concentration of DNA was measured spectrophotometrically (Nanodrop ND-1000 Thermo Fisher scientific Inc., USA). The rDNA ITS region was amplified by conventional PCR using the primers ITS5 and ITS4 (WHITE et al., 1990). Purified sequence reactions were analyzed on an ABI Prism 3730 Genetic Analizer (Life Technologies). The sequences obtained after manual editing were blasted in NCBI database using the BLASTn program (http://blast.ncbi.nlm.nih.gov).

\section{RESULTS}

The Geosmithia genus was identified according to macro-and micro-morphological criteria. Growth was slow and restricted to room temperature, but it was enhanced at $30^{\circ} \mathrm{C}$, with colonies reaching $2-3 \mathrm{~cm}$ in diameter after 10 days at this temperature. Microscopic analysis revealed the presence of hyaline, rough-walled, septate, and often branched conidiophores. These conidiophores bore quaterverticillate- or terverticillate- asymmetrical Penicillium-like and had phialides with a tapering tip that was parallel to the axis. Conidia were smooth-walled, hyaline, and cylindrical to ellipsoidal (Fig.II). Morphological identification of the two monosporic isolates (CREADC-F2469, CREADCF2470) was confirmed by molecular sequence comparison with $100 \%$ identity with Geosmithia pallida (G. Sm.) M. Kolarik, Kubatova \& PaOUTOVA and 99\% identity with Geosmithia langdonii, respectively as the highest identity percentages retrieved from BLAST searches. These sequence data have been submitted to the GenBank databases (ncbi.nlm.nih.gov/genbank) under the accession numbers MW627331 and MW627364.

\section{DISCUSSION}

Geosmithia species are cosmopolitan but understudied fungi. Most of them are associated with phloem-feeding bark beetles colonizing various woody hosts. Geosmithia pallida is an emerging pathogen of live oak in the United States (LYNCH et al., 2014) showing affinities with a wide range of wood-boring insects, such as bark beetles and sawyer beetles (KOLARIK et al., 2004). VANNINI et al. (2017) has recently found this fungal species on Quercus ilex L., Pistacia lentiscus L. and Viburnum tinus L., during a survey conducted in the Circeo National Park 


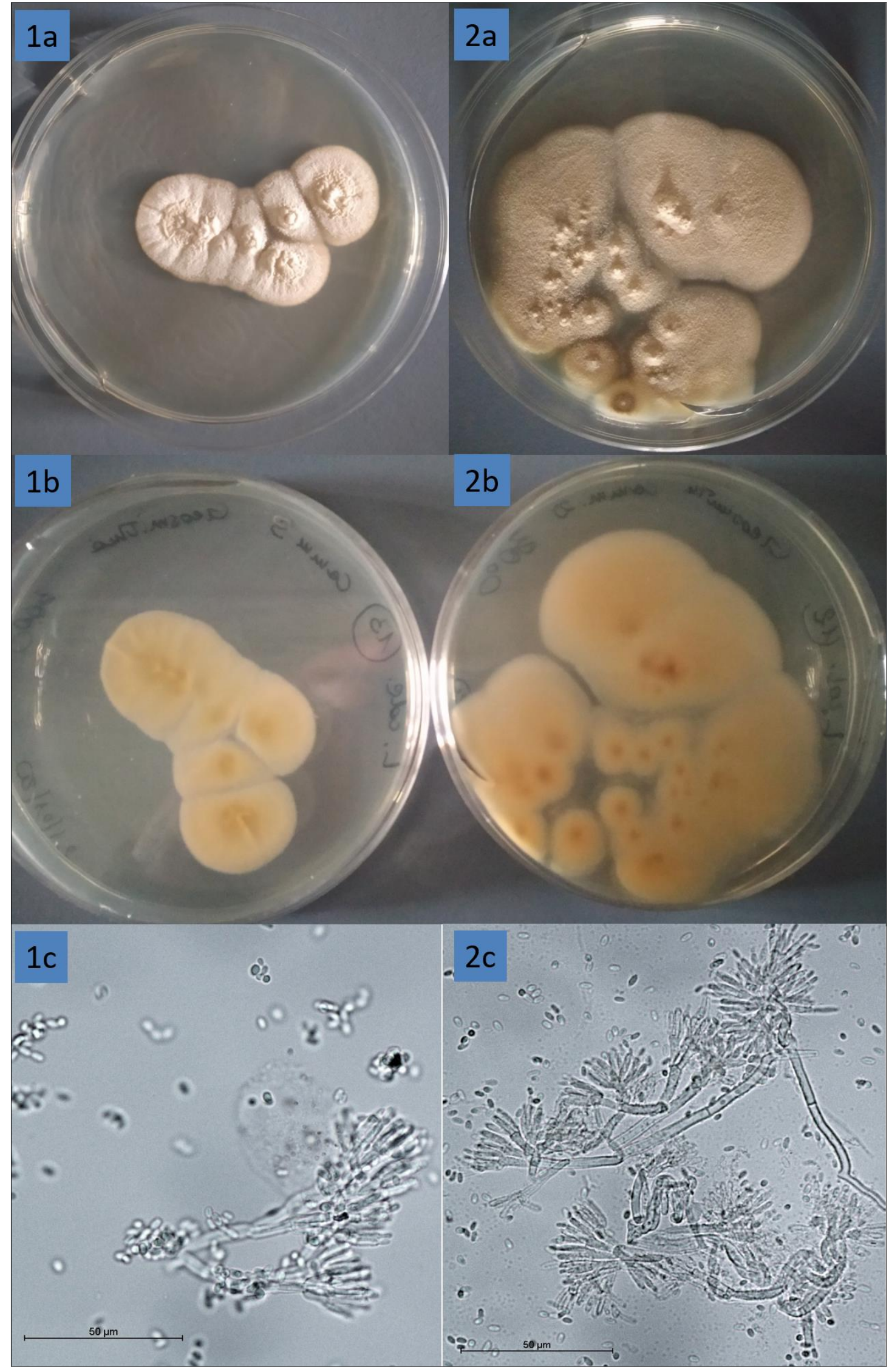

Fig. II - Colonies of Geosmithia langdonii (1a and 1b) and Geosmithia pallida (2a and 2b) grown on Potato Dextrose Agar (PDA) medium. Conidia and branched conidiophores of G. langdonii (1c) and G. pallida (2c) respectively. 
- Latium region (Italy). Geosmithia langdonii, on the other hand, was discovered in association with Scolytus intricatus on several oak species (KOLAŘ́K et al., 2005, 2007) and it was described as associated with Platypus cylindrus in wilted cork oaks (Quercus suber L.) in Algeria (BELHOUCINE et al., 2011). More recently, it has been also isolated from a decaying elm (Ulmus minor Mill) in Switzerland (HÄNZI et al., 2016).

To our knowledge this is the first report of G. pallida and $G$. langdonii associated with $L$. colchicum. Further research is, nonetheless, required to fully evaluate the potential role of this scolytid in the transmission of Geosmithia species.

\section{ACKNOWLEDGEMENTS}

The study was performed within the project "Contributi per il controllo delle emergenze fitosanitarie determinate da Xylosandrus compactus, Xylella fastidiosa, Bortytis cinerea - (CO.XI.BO)" (D.M. 0037134 of $31 / 12 / 2018$ ) funded by the Ministry of Agricultural, Food and Forestry Policies-MiPAAF.

The Authors are grateful to the Dukes Salviati for the permission to conduct surveys in the Park of Villa Salviati in Migliarino (Pisa). We also thank Ms Silvia Cinacchi and Mr Paolo Marradini for logistic support in field.

\section{REFERENCES}

Belhoucine L., Bouhraoua R.T., Meijer M., EquihuA-Martinez A., Pujade-VILlar J., 2011 Mycobiota associated with Platypus cylindrus (Coleoptera: Curculionidae, Platypodidae) in cork oak stands of North West Algeria, Africa. - African Journal of Microbiology Research 5 (25): 4411-4423. http://doi: 10.5897/AJMR11.614.

Benvenuti C., Strangi A., Iovinella I., BarzantI G.P., Simoni S., BinAzZI F., PENNACChIO F., VitAle S., LUONGO L., FRANCARDI V., ROVERSI P.F., 2021 Xylosandrus compactus and Liparthrum colchicum in Tuscany: a preliminary screening of associated fungi. - Redia, 104: 139-146. http://dx.doi.org/10. 19263/REDIA-104.21.14.

FranCARDI V., Vitale S., STRANGI A., BINAZZI F., BENVENUTI C., BARZANTI G.P., LUONGO L., LANDI S., PENNACCHIO F., 2021 - Liparthrum colchicum Semenov (Coleoptera Curculionidae Scolytinae) in Italy: introduced, established or native species?.- Redia, 104: 55-61. http://dx.doi.org/10.19263/REDIA-104. 21.06

HÄnZi M., COChard B., Chablais R., Crovadore J., LEFORT F., 2016 - First report of Geosmithia langdonii and Geosmithia spp. isolated from a decaying elm (Ulmus minor) in Geneva, Switzerland. - Folia Forestalia Polonica, Series A 58 (2): 96-102. http://doi: https://doi.org/10.1515/ffp-2016-0011.

JORDAL B.H., KIRKENDALL L.R., HARKESTEAD K., 2004 - Phylogeny of a Macaronesian radiation: host plant use and possible cryptic specification in Liparthrum bark beetles. - Molecular Phylogenetics and Evolution, 31: 554-571.

Kolarik M., Kubatova' A., Pazoutova S., SRUtKa P., 2004 - Morphological and molecular characterisation of Geosmithia putterillii, G. pallida comb. nov. and G. flava sp. nov., associated with subcorticolous insects. - Mycological Research 108: 1053-1069. https://doi.org/10.1017/S095375620400 0796.

KolaŘíK M., KubÁtová A., CEPICKA I., PAZOUTOVÁ S., SRŮTKA P., 2005 - A complex of three new whitespored, sympatric, and host range limited Geosmithia species. - Mycological Research 109: 1323-1336. https://doi.org/10.1017/S0953756205003965.

KolAŘíK M., KostovcíK M., PAZOUTOVÁ S., 2007 Host range and diversity of the genus Geosmithia (Ascomycota: Hypocreales) living in association with bark beetles in the Mediterranean area. Mycological Research 111: 1298-1310. https://doi. org/10.1016/j.mycres.2007.06.010.

LYNCH S.C., WANG D.H., MAYORQUIN J.S., RUGMANJONES P.F., STOUTHAMER R., ESKALEN A., 2014.First Report of Geosmithia pallida causing foamy bark canker, a new disease on coast live oak (Quercus agrifolia), in association with Pseudopityophthorus pubipennis in California. Plant Disease APS PUBLICATIONS 98 (9), 1276. https://doi.org/10.1094/ PDIS-03-14-0273-PDN.

Rassati D., Faccoli M., Petrucco Toffolo E., BATTISTI A., MARINI L., 2015 - Improving the early detection of alien wood-boring beetles in ports and surrounding forests. - Journal of Applied Ecology, 52: $50-58$.

VANnini A., Contarini M., Faccoli M., Della Valle M., Rodriguez C.M., MAZZETTO T., GUARNERI D., VETTRAINO A.M., SPERANZA S., 2017 - First report of the ambrosia beetle Xylosandrus compactus and associated fungi in the Mediterranean maquis in Italy, and new host-pest associations. - OEPP/EPPO Bulletin 47 (1): 100-103. https://doi.org/10.1111 / epp. 12358 .

White T.J., BRUnS T., LEE S., TAYlor J., 1990 Amplification and direct sequencing of fungal ribosomal genes for phylogenetics. In: PCR protocols, a guide to methods and applications (eds.: M.A. Innis, D.H. Gelfand, J. Shinsky, T.J. White). Academic Press, San Diego. 